\title{
A Country Profile of the Role of English in Kenya
}

\author{
Liang Chu \\ School of Foreign Studies \\ Xi' an University \\ Xi' an, China
}

\begin{abstract}
The development of world English has become a hot issue that draws an increasing attention from the researchers. How should we deal with the relationship between the UK English - the so-called internal English and the English used in non-native countries - the so called world English. How does the world English develop into its present position? The answers of those questions would be the key to the studies of English language education as well as the national language policy. Thus, this paper attempts to, take Kenya English as a typical example, address the question of how world English develop into its present role and what are the critical influential factors.
\end{abstract}

Keywords-world english; english in kenya; political and social and educational factors

\section{INTRODUCTION}

Lying across the equator in east-central Africa, on the coast of the Indian Ocean, the republic of Kenya is the primary focus of all adventure travel in Africa. It is one of the finest and undoubtedly the most famous - safari destination in the world (CIA, 2003). Now Kenya has become one of the biggest tourist attractions in Africa, in which the service sector accounted for almost two thirds of GDP in 2004, followed by industry at about 19 per cent and agriculture at over 16 per cent.

\section{LINGUISTIC BACKGROUND IN KENYA}

For its special geographical location, the region has long been a migratory path, passed through by wave upon wave of peoples from all over Africa and the Middle East and, later, from Portugal and Britain as well. All this has made Kenya a quite linguistically complex country, or in other words - a multilingual country. The Bantu Swahili language and English are widely spoken as lingua franca, and are the two official languages. Generally, languages spoken in Kenya fall into two categories - the African languages and the Non-African languages, each of which could be further divided into different linguistic groups. The African languages include Bantu, Para-Nilotic, Nilotic and Cushitic (Whiteley, 1974) and the Non-African languages are mainly Asian, European and Arabic languages. Of the various categories, the Bantu group forms the largest linguistic group out of the four African language groups while English takes the lead among the NonAfrican languages.

\section{THE Historical Role OF ENGLish IN KENYA}

With the arrival of the Portuguese at the end of the 15th century, the East African coastal region was for a time dominated by the Europeans. However, in 1729 the Portuguese were expelled, to be replaced by two Arab dynasties. Arab rule lasted until the end of the 18th century, and in the year of 1895 , Kenya passed into the British sphere of influence. It is at this time that English began to widely spread. By then, however, Swahili had not only long established itself in the coastal town Mombasa, the former capital city of Kenya, but also extended along the east coast line to most parts of the East African coast as a result of the trade contact between the Bantu-speaking groups and the immigrant races. And this is, surely to some extant, setting a barrier to the spreading of English.

To address this problem, the British colonial government settled on the movement of its capital from a mainly Bantuspeaking city Mombasa to Nairobi, which is farther interior, thus much less influenced by the Swahili. With the move of administration to Nairobi, the focus was no longer on Mombasa and Kiswahili, the language at the coast.

However, the massive spreading of English did not take place as expected, for the impact imposed by the varying attitude toward English of the contemporary government, missionaries, and the European settler farmers, which could play a primary role in helping locals get early exposure to the English language. To many of the settlers, separating English from the Africans was a way of retaining cheap labour. They hold that "English should not be taught to people destined to till the land"(Crampton, 1986). Therefore, it is an effective way to downgrade the status of the local socially, economically and politically. The same case but for different purpose is true of those missionaries, who believed that "Africa would be converted by Africa" (Gorman, 1974: 404; Abdulaziz, 1982: 97). As a result, they started to translate the Bible into local languages, most of which turned out to be Kiswahili.

The year 1909 saw a significant change in the promotion of English in Kenya as there was a general acceptance that English should be introduced in the African schools. The reasons are various. For one thing, the colonial government needed more skilled workers for which the use of English was a prerequisite. For another, the local Africans were eager to participate in the political affairs for which the use of English is a must.

\section{The PRESENT Role OF ENGLISH IN KENYA}

Since Kenya gained her independence in 1963, the repaid expansion of English continued. Now, as one of the national languages, English holds a more prominent role in the various 
sectors of the country. From the internet, business, radio and television to school education, service industry and political conference, English has been closely linked with every aspect of the local people's daily life. One of the major causes that lead to English's prevailing status in this country is Kenya's strategic geographical location. Its main seaport, Mombasa, serves the rest of the East African countries. If tourists and other visitors come to East Africa across the sea, they must pass through Kenya. Accordingly, a number of employment opportunities will be brought about, which will, in turn, highly motivate the local people to learn English. What is more, language policy has made its own contribution to facilitate its dominant position, since English is mainly acquired through school. As early as 1963 when Kenya attained self rule, English was declared the official language, and one year later, introduced as the only compulsory medium of instruction from the beginning class in primary school to the university level. Besides, the most important two educational tests-Kenya Certificate of Primary Education (KCPE) and Kenya Certificate of Secondary Education(KCSE) - required English as a compulsory subject.

Nevertheless, the seemingly irreplaceable role of English in Kenya is not unshakable. Many social factors may also undermine its solid foundation. The first one is with regard to the not so positive attitude of Kenyans towards the English language. As Jomo Kenyatta, Kenya's first president, said, "The basis of any independent government is a national language and we can no longer continue aping our colonizers"(Crystal: 114). Thus it began to foster a sense, amongst the local people, that the Kenya culture identity should be reenforced by means of using their own intrinsic language, say Kiswahili. Many Kenyans were especially in favor of Kiswahili in education for the sake of national and regional unity and the Pan-Africanism dream (Mazrui \& Mazrui 1996). Then, the Authentity of the English language heritage became another challenge. Unlike the past situations, the present fact that the language teacher is a non-native speaker who has been taught and trained by non-native users of English made the teaching of standard variety of English a really tough job. Consequently, English teachers are always in a dilemma, as is indicated by Dr Angelina N. Kioko in her paper, "Those doing research into the New English tell the teacher that a variety or several varieties of a New English exists. However, the teacher is often told by the authorities that it must not exist, that it is up to himor her to 'teach it away'and that it is his/her fault that it is still there."(Angelina \& Margaret, 2001, p. 206-207)

\section{CONCLUSION}

The findings of this profile has shown how English language in Kenya survived from the complicated linguistic context and developed into its present prestigious position. On the other hand, the influential factors from political, social and educational field will increase uncertainty on whether English is likely to proceed with the priority in Kenya, English is quickly establishing itself as an international language though.

\section{REFERENCES}

[1] Abdulaziz, M. (1982) Patterns of language acquisition and use in Kenya: Rural-urban differences. International Journal of Society and Language 34, 95-120.

[2] Angelina N. Kioko and Margaret J. Muthwii (2001) The Demands of a Changing Society:English in Education in Kenya Today. LANGUAGE, CULTURE AND CURRICULUM, 14 (3), 206-207.

[3] CIA (2003) Kenya Government. The World Factbook 2003. Retrieved March 1, 2004, from http://www.odci.gov/cia/publications/factbook/ke/govern/html.

[4] Crampton, D. (1986) Language policy in Kenya. Rassegna Italiana Linguistica Applicata 18 (3), 109-22.

[5] Crystal, David (1997) English as a Global Language. Cambridge: Cambridge University Press.

[6] Gorman, T.P. (1974) The development of language policy in Kenya with particular reference to the educational system. In W.H.Whiteley (ed.) Language in Kenya. Nairobi:Oxford University Press.

[7] Mazrui, A.A. \& Mazrui, A.M (1996). "A tale of two English: The imperial language in the post-colonial Kenya and Uganda". In: Fishman, J. Conrad, A. \& Lopez, A.L. (eds.) Post Imperial English. Berlin: Mouton de Gruyter, 271-302.

[8] Whiteley, Wilfred, H. (1974) Language in Kenya. Nairobi: Oxford University Press. 